\author{
Аникин Даниил Александрович, \\ доиент, канд. филос. наук, \\ ФГБОУ ВО «Саратовский государственньй университет \\ имени Н.Г Черныпевского», \\ 2. Саратов, Россия
}

КОНТУРЫ ПОСТСЕКУЛЯРНОГО ОБЩЕСТВА: ПОЛИТИЧЕСКИЕ ОСНОВАНИЯ И СИМВОЛИЧЕСКИЕ РЕСУРСЫ

В статье рассматриваются основные концепции постсекулярного общества и выявляется роль прошлого в качестве символического ресурса легитимации религиозного сообщества. Специфика постсекулярного общества заключается в политизации религии и включении религиозных трактовок прошлого в символическую конкуренцию политических акторов.

Ключевые слова: память, символические ресурсы, постсекулярное общество, религия, политика.

Daniil A. Anikin, assistant professor, Ph.D in Philosophical sciences, FSBEI HE «Saratov State University named after N.G. Chernyshevsky»,

Saratov, Russia

\title{
THE OUTLINES OF A POST-SECULAR SOCIETY: POLITICAL REASONS AND SYMBOLIC RESOURCES
}

The article deals with the basic concepts of post-secular society and reveals the role of the past as a symbolic resource of the religious community legitimization. The specificity of postsecular society is the politicization of religion and the inclusion of religious interpretations of the past in the symbolic competition of political actors.

Keywords: memory, symbolic resources, post-secular society, religion, politics.

Постсекулярные тенденции в развитии современного общества были диагностированы исследователями еще в 80-ые годы XX века, но только в последнее время теория постсекулярного общества становится полноценной моделью общественного развития. Вместе с тем, усиление внимания к 
религиозным ценностям как существенному фактору социальных трансформаций означает углубленную проработку экспансии данных ценностей в различные сферы общественной жизни.

М. Вебер считал, что процесс секуляризации совпадает с процессом демократизации и рационального переустройства общества на легальнорациональных основаниях. Рационализация человеческого мышления приводит к пересмотру отношения к религии, прежде всего, в политическом смысле, поскольку меняется тип легитимности политической власти. В первую очередь религия строится на господстве традиции, что становится нерациональным в эпоху операциональности и эффективности выполняемых действий. Религиозные институции начинают устраняться из социальной жизни, а сам процесс радикального переустройства ценностных ориентацией можно назвать «расколдовыванием мира».[2, с. 56-58] Но уже Вебера заботил существенный аспект подобного процесса, а именно то, что построенное на господстве закона общественное устройство теряет те символические основания, которые способствовали его укреплению в предшествующие эпохи. Именно ослабление символических связей между представителями одного сообщества заставляет его прийти к мысли (значительно ослабляющей четкую схему распределений типов легитимности), что легальная власть обязательно должна дополняться либо символической традицией, либо личной харизмой правителя.

Ю. Хабермас, впервые заговоривший о феномене постсекулярного общества, считал его закономерной стадией развития модерна и тех тенденций, которые были заложены еще в эпоху Просвещения. Именно тогда возникла публичная сфера, которая естественным образом стремится преодолеть власть религиозных институций, и в этом стремлении осуществляет процесс устранения религии из социальной и политической сферы[4, с. 40]. Впрочем, это устранение оказывается временным и ошибочным, поскольку утрата символического ресурса религии приводит к чрезмерной рационализации человеческого поведения, разрушению коллективных рамок, без которых затруднительной оказывается консолидация сообщества. 
Целью функционирования публичной сферы является достижение консенсуса, условием чего становится вовлечение в процесс делиберативного общения всех социальных и политических акторов, заинтересованных в решении данного вопроса. Поэтому возвращение религии во многом запрограммировано логическим развитием демократических тенденций, результатом чего становится включение религиозных сообществ в процесс коллективного обсуждения ключевых вопросов.

В постсекулярном обществе происходит возвращение религии как социального института и религиозного сообщества в качестве распространенной разновидности социальной группы. Из личного дела каждого человека религиозная идентичность превращается в важный фактор консолидации, что актуализирует значимость коллективной памяти в качестве символического ресурса. Выступая субъектом публичного диалога, религиозное сообщество нуждается в уменьшении внутренних противоречий и подчеркивании внешних границ, поэтому обращение к особой традиции становится важным фактором религиозной идентичности. Правда, не стоит преувеличивать объективность существования подобной традиции. Существенным становится, скорее, подчеркивание ее непрерывности и преемственность, нежели реальная тождественность конкретных религиозных практик [5, с. 226-232].

Ж. Корм подходит к проблеме постсекуляризма с другой стороны. Для него религия сама по себе является символическим ресурсом в руках определенных политических сил [3, с. 11-12]. В этом смысле религиозная идентичность действительно может приобретать доминирующее значение, но кардинально меняется последовательность совершаемых действий. Первичным является стремление определенной политической элиты к власти, которое достигается путем постулирования определенных религиозных ценностей, а уже следствием указанной тенденции становится создание сообщества, для которого превалирующими становятся именно религиозным ценности. Подтверждение своим рассуждениям Корм видит в примере Ирана, где 
исламская революция и усиление религиозного фундаментализма стали следствиями внутренней политической борьбы, а восстановление религиозных ценностей стало удобной целью для формулирования и продвижения политической программы.

Таким образом, постсекуляризм выступает не естественной логикой развития демократии как модернистского проекта, а свидетельством кризиса постмодернизма в качестве претензии на поликультурность и господство универсальных оснований для диалога. В рамках трактовки Кормом понятия постсекулярного общества существенным становится признание политической борьбы в качестве источника формирования общественного запроса на религиозные ценности. Религия выступает в качестве важного символического ресурса, а само по себе постсекулярное общество реанимирует пространство религиозных войн в качестве фактора геополитического противостояния.

Постсекуляризм обладает своеобразными пространственными характеристиками, поскольку означает символическое перемаркирование социального пространства, о чем напоминает П. Бурдье в своих работах, посвященных религиозному полю. Он отмечает, что религиозное поле подчиняется общим закономерностям функционирования символического пространства, но обладает своими специфическими характеристиками, наиболее существенной из которых является своеобразная форма распределения символических ресурсов. «Логика рынка религиозных благ такова, что за любое усиление монополии Церкви, то есть за любое расширение или увеличение мирской и духовной власти духовенства над мирянами (к примеру, проповедь Евангелия), ей приходится платить все большими уступками, как на уровне догмы, так и на уровне литургии, в пользу религиозных представлений мирян, поскольку в противном случае она рискует потерять своё влияние» [1, с. 7]. Иначе говоря, в условиях постсекулярного общества конкуренция в символическом пространстве строится по законам рыночной экономики, при которой ведущую роль начинают играть желания и запросы потребителя. В такой ситуации даже религиозные институции 
вынуждены стремиться к расширению своего влияния путем облегчения груза обязательств и санкций, но при этом специфика постсекулярного состояния заключается в стремлении не просто отстоять собственные ценности от внешних посягательств, но и обеспечить распространение собственных ценностей.

Важно понимать, что практики поддержания коллективной памяти религиозного сообщества приобретают не только символическое, но и вполне материальное значение, поскольку означают претензию на реституцию церковного имущества, что оказывается особенно важно в условиях современного российского общества. Наличие религиозных ценностей становится фактором легитимации претензий на реализацию собственных политических и экономических интенций, что и определяет производство и подбор символических ресурсов, стремление расширить их базу за счет присвоения общезначимых образов прошлого.

Статья подготовлена при поддержке гранта РФФИ 18-311-00212

«Коллективная память религиозных сообществ в постсекулярном мире:

формыл идентичности и социальные практики»

\section{СПИСОК ЛИТЕРАТУРЫ}

1. Бурдьё П. Генезис и структура поля религии // Социальное пространство: поля $и$ практики: сборник статей. - Москва, 2005. - С. 5-32.

2. Вебер М. Избранные произведения. - Москва: Прогресс 1990. - С. 56-58.

3. Корм Ж. Религиозный вопрос в ХХІ веке. Геополитика и кризис постмодерна. - Москва: Институт общегуманитарных исследований, 2012. - 288 с.

4. Хабермас Ю. Теория раџุинализаџии Макса Вебера // Соџиологическое обозрение. - 2009.

- T. 8, № 3. - C. 37-60.

5. Хальбвакс М. Социальные рамки памяти. - Москва: Новое издательство, 2007. - С. 226232. 